\title{
THE STRUCTURE OF SECRETORY TISSUE OF THE STIGMA AND SEPTAL NECTARIES AS WELL AS NECTAR SECRETION OF FLOWERS OF Hosta fortunei BAKER L. H. BAILEY (FUNKIACEAE)
}

\author{
Mirosława Chwil \\ Department of Botany, University of Life Sciences in Lublin, 20-950 Lublin, Akademicka 15, Poland \\ e-mail: miroslawa.chwil@.up.lublin.pl
}

Received: 17.01.2009

\section{Abstract}

A study of Hosta fortunei Baker L. H. Bailey (Funkiaceae) flowers was conducted in the years $2007-2008$. The flower life span and flowering duration as well as the nectar production rate were determined. The structure of the tissues of the stigma and nectary was investigated using stereoscopic, light and scanning electron microscopy (SEM).

The plants flowered over a period of five weeks. Flowers of $H$. fortunei lived two days, on the average. Developed a pistil with an elongated ovary terminating in a discal stigma. On the surface of the stigma, unicellular glandular trichomes grew densely, composed of a stalk with a length of $113-213 \mu \mathrm{m}$ and a head which was characterised by a large diameter range of $54-96 \mu \mathrm{m}$. The cuticle on the apical surface of a part of the trichomes was smooth, whereas it was striated on the stalk. Their protoplast was characterised by dense cytoplasm and weak vacuolisation. In the head of the trichomes fatty substances were accumulated. Septal nectaries occurred in the ovary of the superior pistil. Nectar was exuded onto the surface through three openings, situated in the upper part of the ovary of the pistil. At these places, epidermal cells formed a smooth or slightly wrinkled cuticle. The outer walls of the cells of the epidermis covering the duct accumulating nectar were thick. The glandular tissue of the nectary was made up of 2 layers of different-shaped, thin-walled cells and a deeply stained protoplast. They contained dense cytoplasm and a large, frequently lobate nucleus. At the final stage of secretion, fine vacuoles were observed in the cytoplasm of the glandular cells. Nectar secretion was abundant. In its initial stage, secretion droplets, increasing during the activity of the glandular tissue, were observed on the epidermis surface around the nectar openings. The weight of nectar from 10 flowers was $92.41 \mathrm{mg}$. The sugar concentration in the nectar was within a range of $23 \%-30 \%$, with an average value of $26 \%$. Sugar yield was $23.83 \mathrm{mg} /$ from 10 flowers.

Key words: flowering, nectary, nectar secretion, cuticle, SEM, Hosta fortunei

\section{INTRODUCTION}

The genus Hosta of the family Funkiaceae numbers about 50 species native to China, Korea and Japan. It also includes numerous hybrids and varieties (S z w e y k ow s c y , 2003). In Poland hostas belong to commonly cultivated ornamental plants. They are used as border and ground cover plants and are suitable for planting near water bodies and in wet gardens. These perennials develop ornamental leaves and flower stems. They include plants from dwarf forms to large ones, which differ in growth intensity, shape, colour, leaf size and flowering time (VI - VII) as well as the colour of the perianth which is from white to blue to violet (M a r ink ow s ki, 2002, 2005; Garbarkiewicz and Rak, 2008).

Hosta fortunei is used in breeding to obtain hybrids and to develop new cultivars due to great interest in this taxon on the horticultural market. In addition to their ornamental functions in the garden, plants of the genus Hosta supplement reward for insects in the form of pollen and nectar ( $\mathrm{T} \mathrm{a} \mathrm{k} \mathrm{a} \mathrm{h} \mathrm{a} \mathrm{s} \mathrm{h} \mathrm{i}$ et al. 1993, 1994).

The present study of $H$. fortunei flowers is a continuation of the previously started observations of the structure of septal nectaries in the flowers of Narcissus and Asphodelus (Chwil, 2006; Weryszko-Chmielewska and Chwil, 2007). In literature no data were found on the structure of the nectariferous tissue of plants of the genus Hosta, therefore an attempt was made to supplement such data.

\section{MATERIALS AND METHODS}

A study of flowers Hosta fortunei Baker L. H. Bailey (Funkiaceae) was conducted in the years 2007 - 2008. Plants were observed at the Botanical Garden 
of the Maria Curie-Skłodowska University in Lublin. The flower life span and flowering duration were determined. The structure of the tissue of the stigma and nectary glands was observed at the bud burst stage using stereoscopic, light and scanning electron microscopy (SEM). Under a light microscope, crosssection measurements of cells of the epidermis covering the nectaries and of the glandular layer and of trichomes from the stigma of the pistil were made. The tissues of the stigma were treated with Sudan III and Lugol's iodine solution in order to detect substances accumulated in cells of the trichomes. Micromorphology of the epidermis around the nectar openings and the remaining part of the pistil were investigated using scanning electron microscopy (SEM).

The initial examination of the nectariferous tissues was conducted based on cross-section slides prepared manually from five places: near the nectar openings (the base of the style), along $1 / 4,1 / 2,3 / 4$ sections from the apex of the ovary as well as near its base. In each of the sections prepared, the following measurements were made: radial length and width of the nectariferous tissue, length of the gap accumulating nectar and of the nectar openings. The height of cells of the epidermis covering the nectary and the thickness of the glandular layer were also measured.

Semi-thin sections with a thickness of $1 \mu \mathrm{m}$, prepared using the method described in a paper of W e ry s zk o-Ch mi e lew ska (2003), were used for observations of the cells of the nectary.

The plant material samples for SEM (portions of the ovary of the pistil), after fixing them in glutaraldehyde and dehydrating in acetone, were critical point dried in liquid $\mathrm{CO}_{2}$. Subsequently, these portions were coated with gold and viewed under a TESLA BS-300 microscope.

The nectar production rate was determined using the pipette method (J a b ł o ń s k i , 2002; 2003). Nectar was collected three times using a micropipette at $10^{00}$ from isolated flowers, in five replications. A single replication comprised the nectar secreted throughout the lifetime of $4-5$ flowers.

\section{RESULTS}

The studied plants of Hosta fortunei formed campanulate white-violet flowers borne in onesided racemes (Fig. 1A). These plants flowered over a period of five weeks (in June and in the first decade of July). Flowers lived for two days, on the average. Perianth segments in the lower part formed a straight tube with a length of $12-14 \mathrm{~mm}$, becoming funnel-shaped on a section of $10-12 \mathrm{~mm}$, at the apex forming six lobes with a length of $10-$ $14 \mathrm{~mm}$. The total length of the perianth was $32-40$ mm. Long stamens protruded beyond the perianth (Fig. 1A).

The flowers of $H$. fortunei developed a superior pistil with an elongated ovary (Fig. 1B) $(5-7.3 \mathrm{~mm})$ and a long style $(3.8-5,6 \mathrm{~cm})$ terminating in a discal three-parted stigma with its diameter contained within a range of $1.2-1.4 \mathrm{~mm}$. Unicellular, long glandular trichomes grew densely on the surface of the stigma $(164-289 \mu \mathrm{m})($ Figs $2 \mathrm{~A}-\mathrm{F})$. These trichomes were composed of an elongated stalk with a length of 113 $-213 \mu \mathrm{m}$ and a width of $41-54 \mu \mathrm{m}$ in the middle part and an apex with a different degree of protrusion, which was capitate or globose in its shape (Figs $2 \mathrm{C}-\mathrm{F}$ ). The head of the glandular trichomes was characterised by a large range of diameter - from 54 to $96 \mu \mathrm{m}$. The cuticle on the apical surface of a part of the trichomes was smooth, whereas on the stalk it was striated with a wavy arrangement of the striae in the direction of the long axis of the trichome. The presence of thick cytoplasm and poor vacuolisation of the protoplast in the cells of the glandular trichomes (Figs 2D - F) prove intensive physiological processes. In the cytoplasm of the trichomes head were accumulated fatty substances which showed a positive colour reaction with Sudan III (Figs 2E - F).

The epidermis covering the style of the pistil from the stigma to its base was made up of elongated rectangular-contoured cells. Their outer cell wall developed on its surface striated cuticular ornamentation with the parallel (in the direction of the long axis of the style) arrangement of the striae (Fig. 3A).

At the base of the style, there occurred three radially arranged elongated nectar outlets (Figs 3B - D, 4A-C), beside which droplets of secretion released were observed (Fig. 1B), secreted by the septal nectaries situated in the septa of the ovary of the pistil (Figs 1C, D). The width of the nectar openings ranged $133-304 \mu \mathrm{m}$, and the length of the gap was $620-729 \mu \mathrm{m}$. The epidermal cells around the nectar openings and on the entire surface of the ovary developed cuticle which formed wrinkles arranged in the direction of the long axis of the ovary (Fig. 4C). At some distance from the nectar openings and on the entire surface of the ovary, numerous anomocytic stomata occurred, with different degrees of development (Figs 3C, 4A, B). Alongside open pores, closed pores were also found. The stomatal cells were surrounded by $4-6$ guard cells. The cuticle on the surface of the stomatal cells was smooth, whereas on the guard cells it formed wrinkles, most of which were radially arranged (Fig. 4D).

Three flattened ducts accumulating nectar occurred along the entire length of the ovary, from its base to the nectar openings. The radial length of this gap in the cross section at the base of the ovary was $620 \mu \mathrm{m}$, whereas this space was the largest in the upper part of the nectary $(796 \mu \mathrm{m})$ (Tab. 1). The width of 
Table 1

Results of measurements of tissues of the Hosta fortunei nectary in the ovary cross section.

\begin{tabular}{|c|c|c|c|c|c|c|}
\hline & \multirow{4}{*}{ Investigated trait } & \multicolumn{5}{|c|}{ Place of intersection of the ovary with the nectary } \\
\hline & & \multirow{2}{*}{$\begin{array}{l}\text { nectar } \\
\text { outles }\end{array}$} & $1 / 4$ & $1 / 2$ & $3 / 4$ & \multirow{2}{*}{$\begin{array}{c}\text { ovary } \\
\text { base }\end{array}$} \\
\hline & & & \multicolumn{3}{|c|}{ from the apex of the ovary } & \\
\hline & & \multicolumn{5}{|c|}{$\mu \mathrm{m}$} \\
\hline \multirow{2}{*}{ Radial length } & of the nectariferous tissue layer & 768 & 796 & 704 & 727 & 682 \\
\hline & of the nectar-accumulating gap & 677 & 729 & 622 & 657 & 620 \\
\hline \multicolumn{2}{|c|}{ Height of cells of the epidermis covering the nectary } & \multicolumn{5}{|c|}{$25-35$} \\
\hline \multicolumn{2}{|c|}{ Thickness of the nectar-secreting layer } & 123 & 123 & 106 & 95 & 85 \\
\hline
\end{tabular}
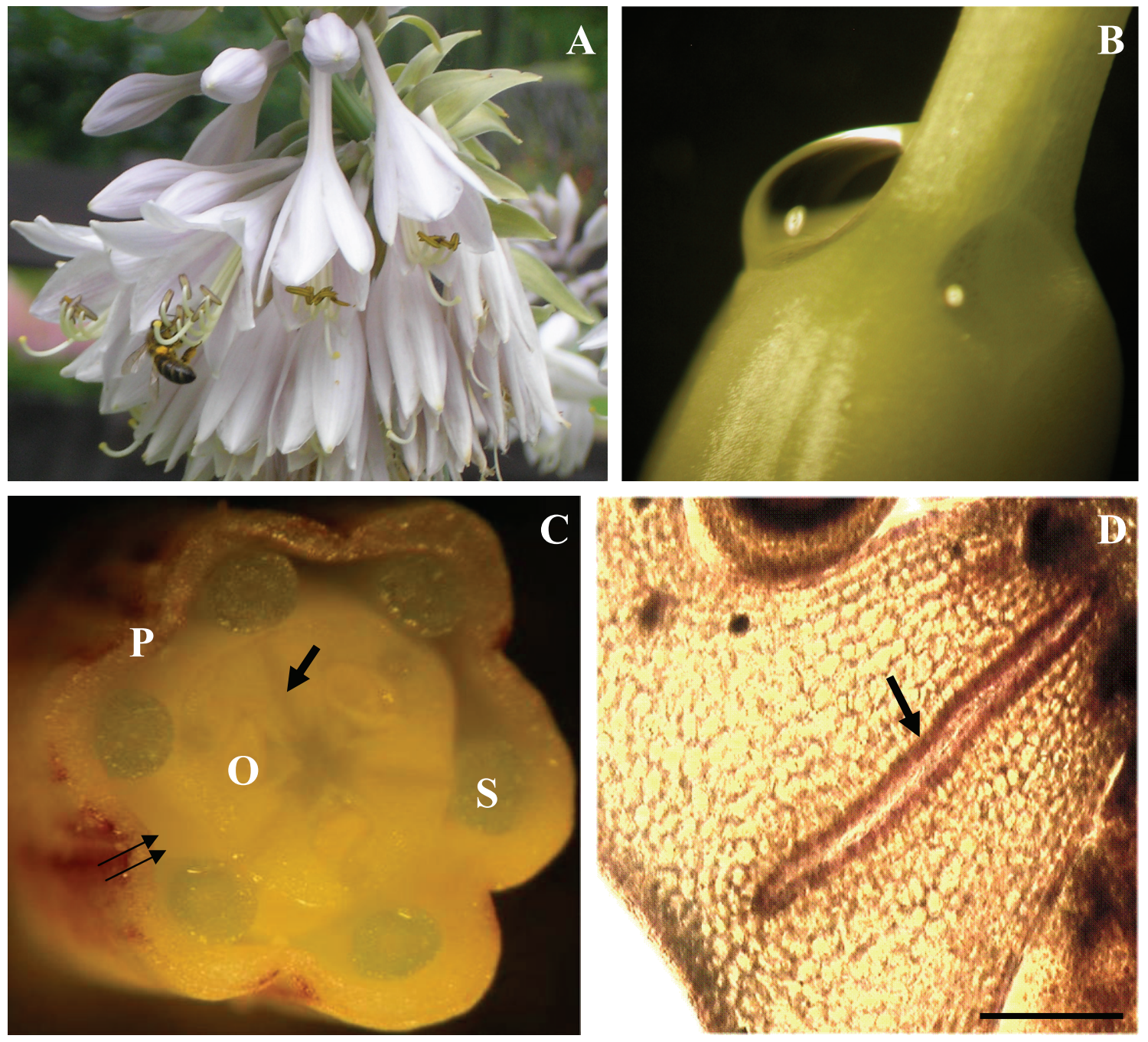

Fig. 1A. Flowers of Hosta fortunei.

Figs 1B - D. Fragments of $H$. fortunei flowers: A - inflorescence, B - nectar droplets at the place of nectar openings, $\mathrm{C}-\mathrm{flower}$ cross-section, visible is the space (two arrows) accumulating nectar, perianth tube (P), stamen filament (S), ovary of the pistil (O) and ovary septa with nectariferous tissue (arrow), D - nectariferous tissue situated in the ovary septum (arrow). $\mathrm{D}-\mathrm{bar}=200 \mu \mathrm{m}$. 

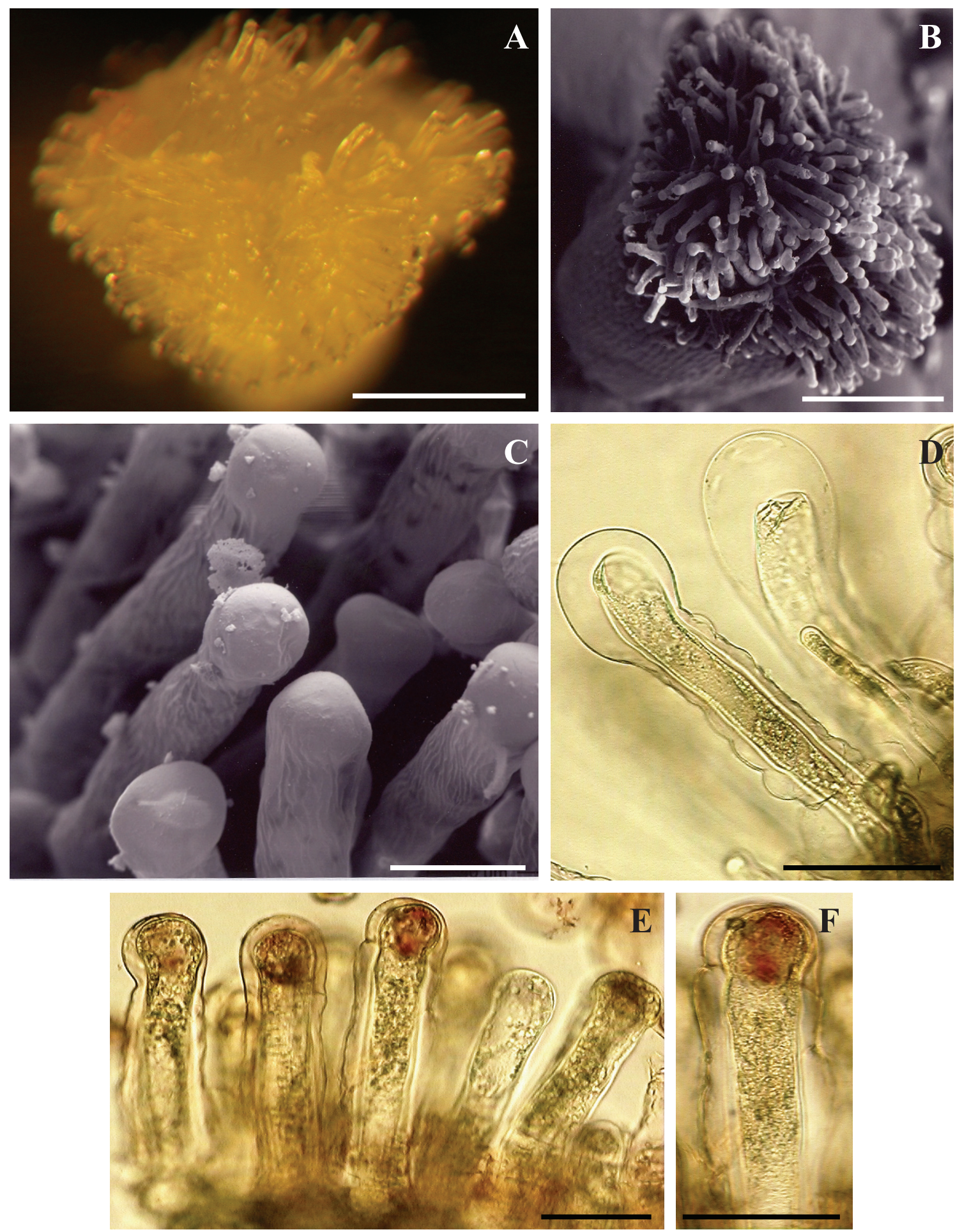

Figs 2A - F. Surface of the stigma of the pistil: visible are densely growing glandular trichomes, with an elongated stalk and a globose head with stained fatty substances. A, B - bars $=500 \mu \mathrm{m} ; \mathrm{C}-\mathrm{F}-$ bars $=50 \mu \mathrm{m}$. 


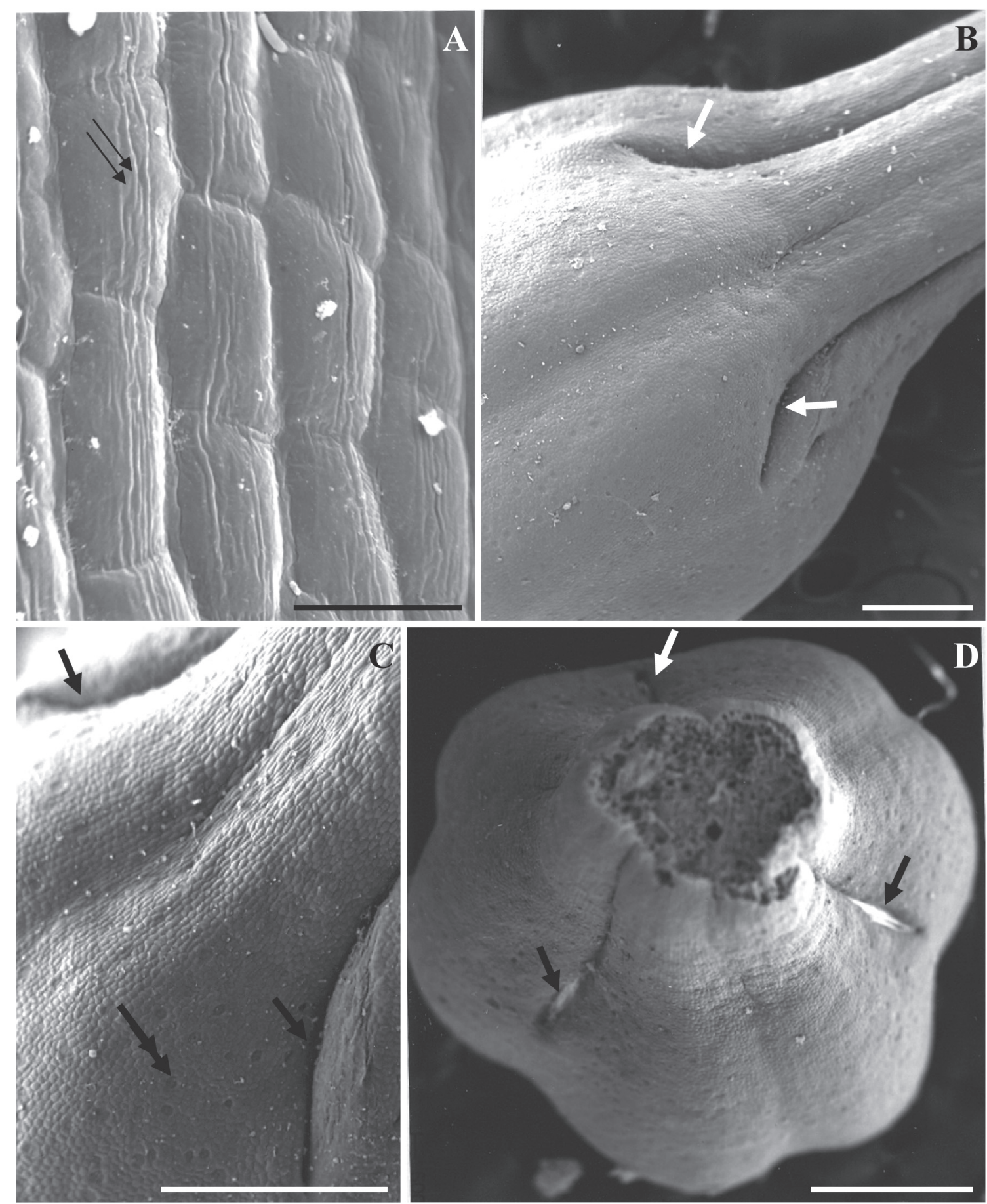

Figs 3A - D. Fragments of the surface of the epidermis covering the pistil: A - epidermal cells covering the style of the pistil, visible cuticular striae (two arrows). Bar $=20 \mu \mathrm{m}$. B $-\mathrm{D}$ - nectar outles (arrow) visible at the base of the style stomata (double arrow). B $-\mathrm{D}-$ bars $=500 \mu \mathrm{m}$. 

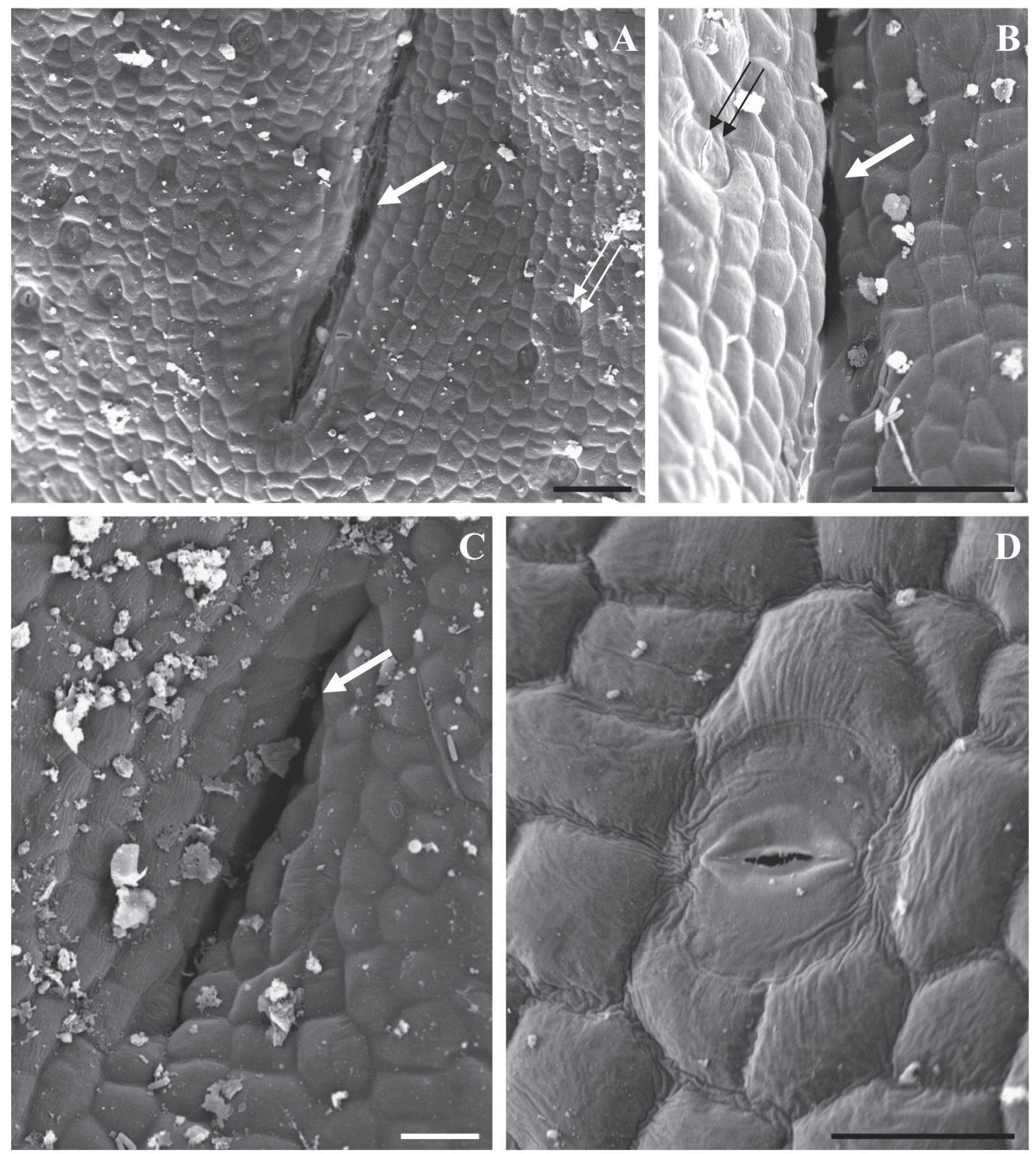

Figs 4A - D. Fragments of the ovary of the pistil, A - C - epidermal cells around nectar openings (arrow), visible stomata (two arrows). $\mathrm{A}-\mathrm{C}-$ bars $=50 \mu \mathrm{m}$. D - stoma. Bar $=20 \mu \mathrm{m}$.

the gap in the examined sections of the nectary ranged between 20 and $76 \mu \mathrm{m}$.

The epidermal cells around the gap accumulating nectar reached a height of $25-35 \mu \mathrm{m}$ (Tab. 1). The cells of the epidermis developed thin, internally tangent and radial cell walls as well as a thick $(10-15 \mu \mathrm{m})$ outer cell wall, more deeply stained. Its inner layer showed undulation of uneven thickness. The protoplast of the epidermal cells was characterised by thick cytoplasm with numerous granulations and a large, frequently lobate cell nucleus (Figs 5A, B). The absence of stomata in the epidermis suggests that nectar secretion up to the vertical gap takes place through the cell walls of the nectary epidermis.

The nectariferous layer in cross sections of the investigated parts of the ovary formed 2 or 3 layers of cells (Figs 5A - D) with a diameter length contained within a range of $682-796 \mu \mathrm{m}$ and a thickness (including the gap) from $145 \mu \mathrm{m}$ up to $226 \mu \mathrm{m}$. These parameters have the lowest values at the ovary base, whereas on a section of L height from the apex of the ovary they increased by $17 \%$ and $56 \%$, respectively, 

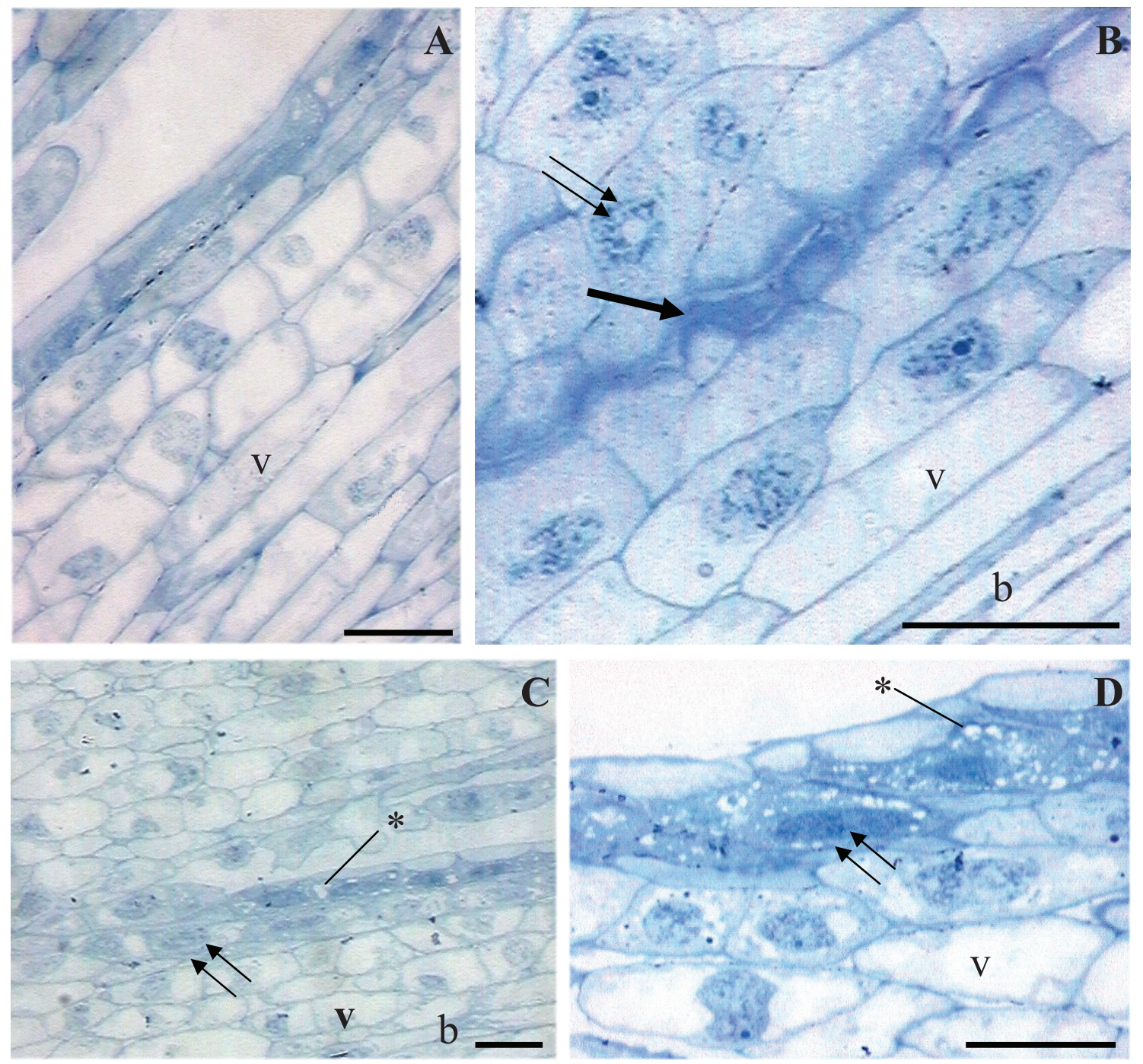

Figs 5A - D. Fragments of cross sections of tissues of the septal nectary in Hosta fortunei flowers, visible are thick outer cell walls of the epidermis (arrow), thick cytoplasm and a large centrally located nucleus (two arrows), fine vacuoles in nectariferous cells at the final stage of secretion (asterisk), vacuolised subglandular cells (v), vascular bundles (b). A - D - bars $=700 \mu \mathrm{m}$.

compared to the dimensions at the place of the ovary base (Tab. 1). The nectariferous cells were slightly elongated with an irregular shape, being quadrangular, pentagonal or hexagonal in their contour; they had thin, cellulose cell walls, thick cytoplasm and a large, lobate, centrally located nucleus (Figs 5B - D). Their protoplast stained more deeply compared to the subglandular cells (Figs 5A-D). At the final stage of nectar secretion, numerous fine vacuoles were visible in the cytoplasm (Figs 5C - D).

The subglandular tissue was composed of elongated cells, strongly vacuolised, with parietal cytoplasm and small intercellular spaces (Figs 5A - D). Vascular elements supplying the nectariferous tissue were found in this layer (Figs 5B-C).
Nectar secretion in the flowers of $H$. fortunei started already at the bud colour and bud swell stages. Initially, small, colourless secretion droplets were observed on the epidermis surface, increasing during the activity of the nectariferous tissue (Fig. 1B), flowing along the ovary of the pistil to the tube of the perianth.

The studied flowers of $H$. fortunei secreted nectar abundantly. The weight of nectar collected from 10 flowers ranged between 68.3 and $130 \mathrm{mg}$, with its average value equal to $92.41 \mathrm{mg}$. The sugar concentration in the nectar was within a range of $23 \%$ up to $30 \%$, with an average value of $26 \%$. Their sugar yield was $23.83 \mathrm{mg} /$ from 10 flowers (Fig. 6). 


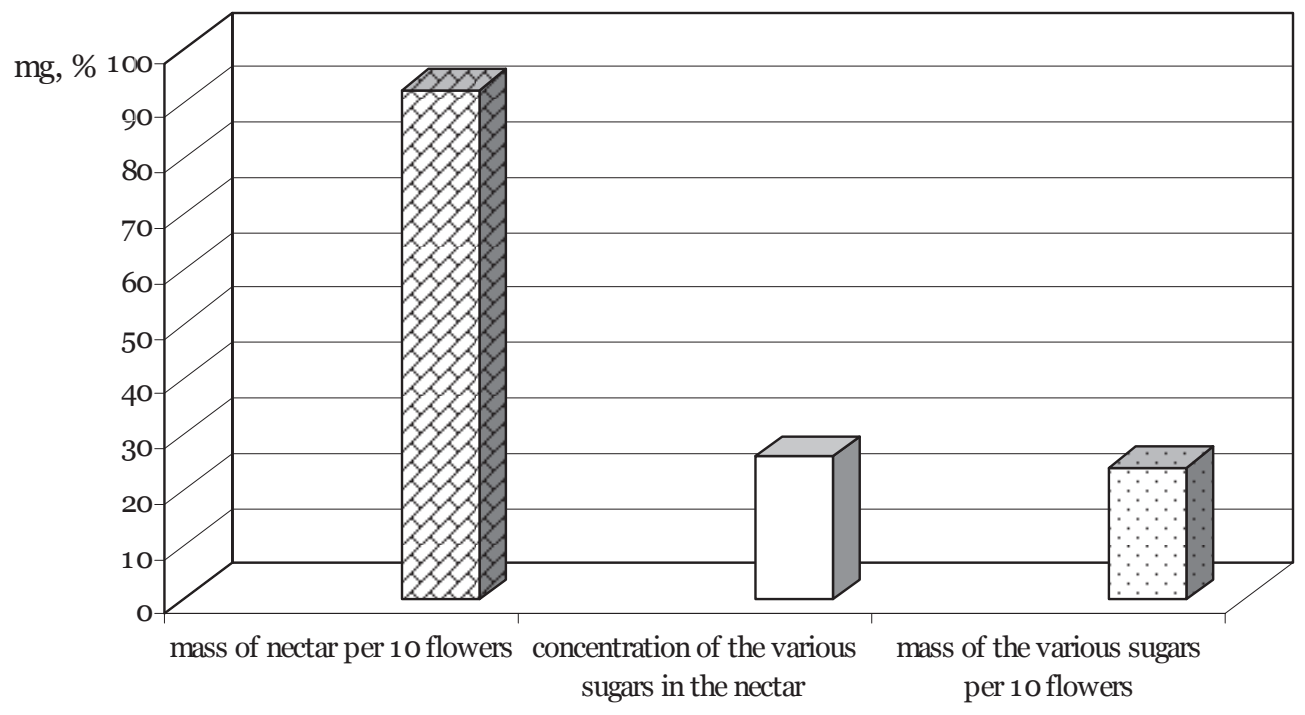

Fig. 6. The nectar production rate of $H$. fortunei.

\section{DISCUSSION}

The septal nectaries, formed along the entire length of the ovary, are responsible for nectar secretion in $H$. fortunei flowers. Literature data show that the location of septal nectaries in the ovary of the pistil is different, depending on the taxon: Acidanthera, Asphodeline, Asphodelus, Narcissus (W e r y s z k oChmielewska et al. 2003; Żuraw, 2005a; Chwil, 2006; Weryszko-Chmielewska et al. 2006; Weryszko-Chmielewska and Chwil, 2007; Sawidis et al. 2008). They are located in the upper or lower part of the ovary. Diversity was also found in their size in the septa of the ovary. In the flowers of Asphodelus aestivus, the nectariferous tissue reached up to $2 / 3$ of the ovary height (W e ry s z k o- C h mi e le w s k a et al. 2006), whereas in the nectaries of Acidanthera bicolor it was approx. $1 / 3$ of the ovary length (Wery s z koChmielewska et al. 2003).

The nectar secreted in the flowers of $H$. fortune $i$ accumulated in narrow ducts located in the septa of the ovary of the pistil, lined with a single layer of epidermal cells. Having been filled up, excess nectar flowed onto the surface of the ovary thorough three longitudinal gaps near the base of the style. A similar location of nectar openings was found in Narcissus flowers (C h w i 1, 2006), whereas in Asphodelus albus they occurred at a certain distance from the base of the style of the pistil (Weryszko-Chmielewska and Chwil, 2007). According to WeryszkoChmielewska and Chwil (2006), the shape of nectar openings in Asphodelus flowers is dependent on the flower development stage. In a closed bud, these places are spherical, subsequently, during flower development, they take on a lenticular form, and at the full flower stage they are elongated and have the largest size.

In the investigated septal nectaries of $H$. fortune $i$ and in those described in literature in the following genera: Acidanthera, Asphodelus and Narcissus, differentsized and shapedcells of the secretory epidermis take part in nectar secretion from the nectariferous tissue (Weryszko-Chmielewska et al. 2003; Chwil, 2006; Weryszko-Chmielewska and Chwil, 2007; Chwil and WeryszkoChmielewska, 2007). In the studied Hosta flowers, in the cross section the epidermal cells were isodiametrically shaped or slightly elongated in the direction of the ovary's radius. But in the flowers of the genus Acidenthera and Narcissus, described in literature, the secretory epidermis layer was composed of palisade-shaped cells (Werys zkoChmielewska et al. 2003; Chwil, 2006).

In the nectaries of $H$. fortunei, glandular cells formed one or two layers and their shape was close to that of parenchymatic cells. In the studies of nectaries of other plant species, different numbers of layers of nectariferous cells were found: $1-3$ in Asphodelus flowers, $2-4$ in the ovary of Acidanthera, and 4 - 6 in Narcissus (Werys zko-Chmielewska et al. 2003; Chwil, 2006; WeryszkoChmielewska et al. 2006).

In the investigated flowers of $H$. fortunei, the septal nectaries were characterised by the largest size in the apical part of the ovary of the pistil. A similar correlation was found in the size of the gap accumulating nectar. According to $\mathrm{W}$ e r y s z k o - C h m i e le w s k a et al. (2003), the shape and size of the septal nectary in the cross section are variable. This gland in the flowers of Acidanthera bicolor is the widest in the middle part 
$(710 \mu \mathrm{m})$, whereas it was about 5 times smaller in the narrowest place $(142 \mu \mathrm{m})$. The gap accumulating nectar in this taxon was three times longer $(2.3 \mathrm{~mm})$ compared to the dimensions of a similar structure in the studied flowers of $H$. fortunei.

The presence of thin cell walls, thick cytoplasm, a large nucleus and the absence of vacuolisation in the nectariferous tissue in the studied flowers of $H$. fortunei are typical for secretory tissues. According to W e r y s z k o- Ch mi e lew s k a et al. (2006) and S a w i d i s et al. (2008), secretory active nectariferous cells of Asphodelus albus and A. aestivus, in addition to the abovementioned cytological traits, were also distinguished by a large number of mitochondria, a welldeveloped endoplasmic reticulum and numerous vesicles of the Golgi body accumulating near the cell wall.

A positive correlation was found between the size of nectariferous tissue and the amount of nectar secreted by the septal nectaries in the flowers of $H$. fortunei and several plant species described in literature (Weryszko-Chmielewska et al. 2003; W e r y s z k o- C h mi e lew s k a and C h w i 1 , 2007). Literature data show that flowers of the genera Acidanthera, Asphodeline, Asphodelus and Narcissus are distinguished by intensive nectar secretion and a high sugar concentration in nectar (W e r y s z k o Chmielewska et al. 2003; Żuraw, 2005a; Chwil, 2006; Weryszko-Chmielewska and $\mathrm{Chw}$ i 1,2007$)$.

Sugar yield from 10 flowers of $H$. fortunei was $23.8 \mathrm{mg}$. Compared to other plants developing sepal nectaries, this value was higher than sugar yield of Allium ursinum ( $8.8 \mathrm{mg})(\dot{\mathrm{Z}} \mathrm{u} \mathrm{r}$ a w , 2005b) and Acidanthera bicolor (10.13 mg) (W e r y s z k oChmielewska et al. 2003), but lower than the value reported for Asphodeline lutea (47.1 mg) and Asphodelus albus (42.2 - 49.5 mg) ( $\dot{\mathrm{Z}} \mathrm{u}$ r a w , 2005a; Weryszko-Chmielewska and Chwil, 2007). Studies show that Hosta fortunei, in addition to being an ornamental plant, is an important taxon offering nectar reward for insects.

\section{REFERENCES}

Chwil M. 2006. 2006. Ekologia kwiatów i morfologia ziaren pyłku wybranych odmian narcyzów (Narcissus pseudonarcissus L. x Narcissus poëticus L.). / Ecology of flowers and morphology of pollen grains of selected Narcissus varieties (Narcissus pseudonarcissus L. x Narcissus poëticus L.). Acta Agrobot. 59 (1): 107-122.

Garbarkiewicz R., Rak J. 2008. Hosty do ogrodów i na balkon. Mutico, Warszawa.

J a b łoń s k i B. 2002. Notes on the method to investigate nectar secretion rate in flowers. J. Apic. Sci. 46 (2): 117-125.
Ja błońs k i B. 2003. Metodyka badań obfitości nektarowania kwiatów i oceny miododajności roślin. Oddział Pszczelnictwa ISK w Puławach.

Marcinkowski J. 2002. Byliny ogrodowe. Państwowe Wydawnictwo Rolnicze i Leśne, Warszawa.

Marcinkowski J. 2005. Katalog bylin polecanych przez Związek Szkółkarzy Polskich. Agencja Promocji Zieleni. Związek Szkółkarzy Polskich, Warszawa.

Sawidis T., Weryszko-Chmielewska E., Anastasiou V., Bosabalidis A. M. 2008. The secretory glands of Asphodelus aestivus flower. Biologia (Bratislava). 63 (6): 1118-1123.

Szweykowscy A., J. 2003. Słownik botaniczny. Wiedza Powszechna, Warszawa.

Takahashi H., Kiriyama Y., Ukai A., Yamada M. 1993. A floral and reproductive biology of Hosta longissima Honda (Liliaceae). Acta Phytotaxonomica et Geobotanica. 44 (1): 11-19.

Takahashi H., Goto Y., Kanematsu S., Niwa S., Mori K., Nozaki K. 1994. Pollination biology of Hosta sieboldiana (Lodd.) Engler and H. sieboldii (Paxton) J. Ingram (Liliaceae). Plant Species Biol. 9: 23-30.

Weryszko-Chmielewska E. 2003. Mikromorfologia kwiatów ruty zwyczajnej (Ruta graveolens L.). I Micromorphology of common rue (Ruta graveolens L.) flowers. Ann. Univ. Mariae Curie-Skłodowska, sect. EEE, 13: 45-51.

Weryszko-Chmielewska E., Chwil M. 2006. Nutritive for insect attractants in Asphodelus albus Miller flowers. Acta Agrobot. 59 (1): 155-164.

Weryszko-Chmielewska E., Chwil M. 2007. Characteristics of the floral nectary and nectar of common bugloss (Anchusa officinalis L.). J. Apic. Sci. 51 (2): 25-30.

Weryszko-Chmielewska E., Masierowska M., Laskowska H. 2003. Budowa nektarnika acidantery dwubarwnej murielskiej (Acidanthera bicolor var. murielae Perry). / Structure of the nectary and nectar production of Acidanthera bicolor var. murielae Perry. Ann. Univ. Mariae Curie-Skłodowska, sect. EEE, 13: 123-127.

Weryszko-Chmielewska E., Sawidis T., Piotrowska K. 2006. Anatomy and ultrastructure of floral nectaries of Asphodelus aestivus Brot. (Asphodelaceae). Acta Agrob. 59 (2): 29-42.

Żuraw B. 2005a. Nektarowanie złotogłowu białego (Asphodelus albus Mill.) i złotnicy żółtej (Asphodeline lutea L.) (Asphodelaceae). / Nectar secretion of white aphodel (Asphodelus albus) Mill. and yellow asphodel (Asphodeline lutea) L. (Asphodelaceae). V Ogólnopolska Konferencja Naukowa. „Biologia kwitnienia roślin i alergie pyłkowe”. Streszczenia, Lublin, 9-10 listopada: 35.

Żuraw B. 2005b. Sekrecja i resorpcja nektaru w kwiatach czosnku niedźwiedziego (Allium ursinum L.) / Secretion and resorption of nectar in flowers bear's garlic (Allium ursinum L.). V Ogólnopolska Konferencja Naukowa. „Biologia kwitnienia roślin i alergie pyłkowe”. Streszczenia, Lublin, 9-10 November: 40. 


\section{The structure of secretory tissue of the stigma and septal nectaries as well as nectar secretion of flowers of Hosta fortunei Baker L. H. Bailey (Funkiaceae)}

\section{Streszczenie}

W latach 2007 - 2008 przeprowadzono badania kwiatów Hosta fortunei Baker L. H. Bailey (Funkiaceae). Określono długość życia kwiatu i kwitnienia roślin oraz obfitość nektarowania. Strukturę tkanek znamienia i nektarnika badano przy użyciu mikroskopii stereoskopowej, świetlnej i skaningowej elektronowej (SEM).

Rośliny kwitly przez okres pięciu tygodni. Kwiaty $H$. fortunei żyły średnio dwa dni. Wykształcały słupek z wydłużoną zalążnią i długą szyjką zakończoną tarczowatym znamieniem. Na powierzchni znamienia wyrastały gęsto jednokomórkowe włoski gruczołowe, zbudowane z trzonka o długości 113 - 213 um i główki, która charakteryzowała się dużą rozpiętością średnicy $(54-96 \mu \mathrm{m})$. Kutykula na powierzchni szczytowej części włosków była gładka, natomiast na trzonku prążkowana. Ich protoplast charakteryzował się gęstą cytoplazmą i słabą wakuolizacją. W główce włosków gromadziły się substancje tłuszczowe. W zalążni górnego słupka występowały nektarniki przegrodowe.
Nektar wypływał na powierzchnię przez trzy ujścia, usytuowane w górnej części zalążni słupka. Komórki epidermy tworzyły w tych miejscach gładką lub lekko zmarszczoną kutykulę. Zewnętrzne ściany komórek skórki okrywającej kanał gromadzący nektar były zgrubiałe. Tkankę gruczołową nektarnika tworzyły 2 warstwy komórek o zróżnicowanym kształcie, cienkich ścianach i intensywnie barwiącym się protoplaście. Zawierały gęstą cytoplazmę i duże, często płatowate jądro. W końcowej fazie sekrecji w cytoplazmie komórek gruczołowych obserwowano drobne wakuole. Sekrecja nektaru była obfita. W jej pierwszej fazie obserwowano na powierzchni epidermy wokół ujść nektaru krople wydzieliny, powiększające się podczas aktywności tkanki gruczołowej. Masa nektaru z 10 kwiatów wynosiła 92,41 mg. Koncentracja cukrów w nektarze wahała się w przedziale $23 \%$ - $30 \%$ ze średnią wartością $26 \%$. Wydajność cukrowa wynosiła 23,83 mg/z 10 kwiatów. 